\title{
Development of sustainable traffic planning: analysis of Danish planning visions 2005 and 2015
}

\author{
S. L. Jeppesen \& S. Leleur \\ Centre of Traffic and Transport, Technical University of Denmark, \\ Denmark
}

\begin{abstract}
Traffic and city planning has for a long period of time been a matter of solving actual problems with specific plans rather than by making visionary long-term planning to prevent new problems from occurring. As the amount of traffic is rapidly increasing and congestion problems are appearing there has, however, been a renewed focus on the interaction between transport and sustainability. To exemplify the advancement of Danish planning methodology this paper in this respect reviews a visionary traffic planning report produced by the Danish Ministry of Transport in 1993 called "Trafik 2005". On this basis a recent set of planning visions for 2015 is examined and by using a simple counting technique the development in Danish transport planning is monitored. Finally some conclusions are given.
\end{abstract}

Keywords: sustainability, traffic planning, visions, monitoring of planning.

\section{Introduction}

Over time different issues and contexts have influenced Danish spatial planning and traffic planning. Based on reviewing recent decades of Danish planning three planning bases have been identified and as a consequence of these, three planning methods as well have been identified, see Table 1 . The planning bases needs, expectations and possibilities are seen as expressions of different planning drivers. Planning based on needs tends to be short-sighted planning, which will handle existing problems without considering how they can be solved on a longterm perspective. Expectations describe planning which is based on forecasts and calculations. This kind of planning tries to adopt a long-term perspective, but can 
be faulty due to the difficulties connected with predicting the future. Possibilities make up a planning basis which takes its origin in what might be possible in the future. This will necessitate that some aspects from needs and expectations have been taken care of, but it is not directly dependent on it [1].

Table 1: $\quad$ Planning bases and planning methods.

\begin{tabular}{|c|c|}
\hline Planning bases & Planning methods \\
\hline Needs & Traditional planning \\
\hline Expectations & Future planning \\
\hline Possibilities & Visionary planning \\
\hline
\end{tabular}

The planning methods have been developed on the outlined planning bases and are referred to as traditional planning, future planning and visionary planning. These planning methods with their different aims can be further characterised as follows.

The traditional planning method seeks to solve the instant planning need. Therefore this kind of planning has been - and will still be - necessary for traffic planning and for planning in other sectors. However, this kind of planning will usually be short-sighted and often further planning will be needed within a relative short period of time. Future planning is an attempt to predict the prospect of the development. This planning method does not try to change the development but tries to make room for it based on predictions and forecasts. This method may rely on calculations and simulations, and though these can be rather uncertain this method does try to set up plans with a long-term perspective. The visionary planning, for example by formulating a set of interrelated visions, provides planners with the possibility to model an ideal world by introducing new thought patterns and in that way create new solutions [2].

In the "Brundtland report" from 1987 the concept of sustainability was originally defined as follows [3]:

"Sustainable development is development that meets the needs of the present without compromising the ability of future generations to meet their own needs".

This has led to many interpretations of the concept. The general assumption has been that sustainability is something related to "green thinking" and environmental goals. To operationalise the concept of sustainability in this context it has been combined with planning and sustainable planning has been defined as [4]:

"A planning methodology, where all implied effects are thought of in such a way that all elements are given influence. Hereby a development which takes care of all apparent needs, without preventing future generations' possibilities for reaching their goals, are sought". 
The main point raised in this respect is that sustainability considerations should be integrated in the actual planning process and its deliberations instead of being a more or less "green attribute" of a resulting planning document. The paper seeks to demonstrate how a more comprehensive view on sustainability and planning can be obtained. The view is associated with the introduced concept of visionary planning, and its potential is demonstrated by analysis of Danish visions for 2005 and 2015 as treated in the following sections.

\section{Analysis of Danish planning visions 2005}

Danish traffic planning has over the years been based on the planning bases and planning methods shown in Table 2. In 1993 the Danish Ministry of Transport published a trend-breaking report called "Trafik 2005" ("Traffic 2005") [5]. The report aimed at giving an overall view of the Danish traffic sector, its goals and possibilities towards 2005 . In this respect a set of visions were formulated with the purpose of guiding action from 1993 towards the target year 2005.

In order to analyse this type of visionary planning the statements and visions contained in "Trafik 2005" have been evaluated to define which kind of strategy/strategies they were actually aiming at. Two strategies have been worked with for this analysis [6, pp. 80-81]:

- passability

- environment \& safety

The passability strategy does to some extent represent a traditional traffic planning strategy, whereas the environment \& safety strategy sets more focus on sustainability issues. In total 42 visions were formulated in "Trafik 2005 ", see [6, pp. 83-87].

A simple methodology was applied to analyze the two strategies about passability and environment \& safety. Thus each vision was categorized as shown on the next page in Table 3 depending on how well it complies with each strategy, and afterwards the two category totals are taken as an indication of the overall match degree between the set of visions and the actual strategy. The actual split of the 42 visions is thereby used to interpret the meaning of the strategy.

The strategy columns sums to 42 , which is the total number of visions in "Trafik 2005". When the visions are evaluated with regard to each strategy the rows do not need to sum up to a fixed number. As can be seen the passability strategy has 10 visions in accordance with it and 7 visions against it, whereas the largest part of visions are placed in the categories between. The larger part of the visions (36 of 42) is in accordance with the environmental \& safety strategy and none of the visions are counter to this strategy. This indicates that the visions, which were outlined in "Trafik 2005", are mainly based on considerations towards environment \& safety.

The presented analysis is based on simple quantitative counting with the content of the visions being evaluated against the two planning strategies. The 
distribution on categories is meant to depict the visionary type of planning carried out along the two strategy orientations. This is but a rough picture but has been adopted as a comparison tool for dealing with a set of planning visions formulated for 2015 .

Table 2: $\quad$ Visions for 2005.

\begin{tabular}{|c|c|}
\hline Vision no. & Keywords of the visions \\
\hline 1 & Denmark as trendsetting nation \\
\hline 2 & Alternative fuel \\
\hline 3 & Quality of life \\
\hline 4 & Employment \\
\hline 5 & Spatial planning \\
\hline 6 & Spread of the rush hour \\
\hline 7 & Traffic calming \\
\hline 8 & Taxes \\
\hline 9 & Technology \\
\hline 10 & Road infrastructure \\
\hline 11 & Choice of transportation mode \\
\hline 12 & Computers in the cars \\
\hline 13 & Intelligent traffic control \\
\hline 14 & Travel card (to pay with) \\
\hline 15 & General traffic safety \\
\hline 16 & High speed trains \\
\hline 17 & Express busses \\
\hline 18 & Financial support to the railway sector \\
\hline 19 & Public transport in Copenhagen \\
\hline 20 & Competitive power of the public transport \\
\hline 21 & Technology in the public transport \\
\hline 22 & Taxi as substitute for public transport in rural areas \\
\hline 23 & Transport supply in the public transport \\
\hline 24 & Contributions to public transport \\
\hline 25 & Domestic air transport replaced by transport by train \\
\hline 26 & International air transport \\
\hline 27 & Train connections to the airport \\
\hline 28 & Improved living conditions at the islands \\
\hline 29 & "Water busses" \\
\hline 30 & Reduction of traffic in the city core \\
\hline 31 & Art in the city room \\
\hline 32 & Road spaces and path networks \\
\hline 33 & City renewal \\
\hline 34 & Use of the road spaces \\
\hline 35 & Speed limits in domestic areas \\
\hline 36 & Shopping centers nearby and combined with stations \\
\hline 37 & Parking houses with a "center function" \\
\hline 38 & Traffic safety in open land \\
\hline 39 & International freight transport \\
\hline 40 & Control of freight transport \\
\hline 41 & Scandinavian freight transport \\
\hline 42 & Distribution of freight \\
\hline
\end{tabular}


Table 3: The 2005 visions related to each of the two strategies.

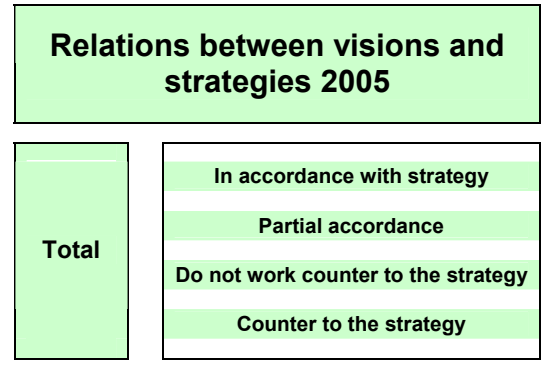

\begin{tabular}{|c|c|c|c|c|c|}
\hline \multicolumn{6}{|c|}{ Strategy } \\
\hline \multicolumn{3}{|c|}{ Passability } & \multicolumn{3}{|c|}{$\begin{array}{c}\text { Environment } \\
\text { \& safety }\end{array}$} \\
\hline 10 & $\sim$ & $24 \%$ & 36 & $\sim$ & $86 \%$ \\
\hline 9 & & $21 \%$ & 1 & $\sim$ & $2 \%$ \\
\hline 16 & & $38 \%$ & 5 & $\sim$ & $12 \%$ \\
\hline 7 & $\sim$ & $17 \%$ & 0 & $\sim$ & $0 \%$ \\
\hline
\end{tabular}

The visions in "Trafik 2005" were set out back in 1993 for the year 2005. Now it is possible to take stock of the visions and their implementation level. The status shows that several of the visions have actually been carried out, but some lack behind due to insufficient financial means and insufficient changes in attitude among road users and politicians and maybe a too optimistic time horizon in "Trafik 2005" especially as concerns infrastructure development and life style.

\section{Analysis of Danish planning visions for 2015}

In a study carried out in 2005 a new set of visions have been set up for the year 2015 [6, pp. 130-135]. These visions, similar to the visions for 2005, are thought to indicate an overall direction for the desired development of the traffic sector comprising also spatial planning.

The visions for 2015 were based on a number of brainstorm sessions, where the current state of the 2005 visions from 1993 where mixed with newly identified visions stemming from the sessions. The process was supported by cognitive maps on selected traffic problems [7]. Table 4 shows the outcome as a list consisting of 68 visions.

The set of the 2015 visions are examined in the same way as the 2005 visions by using four different match categories for the two strategies passability and environment $\&$ safety. The results of the evaluation are given by Table 5 .

It should be noted that for the 2015 visions the columns sum to 68 , which is the total number of the visions. The evaluation once again points out that the larger parts of the visions are in accordance with the environment \& safety strategy. Several of the visions are in accordance with the passability strategy and only a few are counter to this. It should, however, be noted that the relative shares for the two strategies are more even for the 2015 visions than was the case for the 2005 visions. 
Table 4: $\quad$ Visions for 2015.

\section{Vision no.}

2

3

4

5

6

7

8

9

10

11

12

13

14

15

16

17

18

19

20

21

22

23

24

25

26

27

28

29

30

31

32

33

34

35

36

37

38

39

40

41

42

43

44

45

46

47

\section{Keywords of the visions}

Formulation of long-term strategies

Increased role of the regional units

Changed priorities

Influence of the experts

Maintenance

Added capacity to the railroad network

Light-rail at "O3" (a ring road around Copenhagen)

Construction of a harbour tunnel

Metro-city ring line

Long-term traffic planning

Holistic municipality planning

Public Private Partnership (PPP)

More comprehensive appraisals

Soft values in model calculations

Larger accuracy as concerns traffic models

Involvement of citizens

Environment and safety in marketing

Business responsibility

Danish 0-vision for traffic safety

Traffic safety revision as a standard

"VVM" as a standard (Strategic environmental assessment)

Planning of speed profiles

Dynamic road functionality and classification

Improved road user education

Evaluating drivers tests

Driving school education

Improved economic incentives for changes

"A-classification" of vehicles (energy certification)

Road pricing

Vehicle types

Noise reduction at residences

Curbing of congestion

Priority for public transport

Parking strategy

Enlarged rush our

Variable lanes

Increased buss passability

Increased passability on the rail road network

Extended use of trains across Storebælt

Transport of freight by train instead of by truck

Truck-trains to terminals

National zone system (for public transport payment)

Free public transport in the cities

Electronic travel card (for payment)

Improved data related to travel patterns

Information during the journey

Roads that only allow public transport and taxis 
Table 4: $\quad$ Continued.

\begin{tabular}{|c|l|l|}
\hline Vision no. & \multicolumn{1}{|c|}{ Keywords of the visions } \\
\hline 48 & Better conditions for cyclists \\
\hline 49 & Cyclist conditions in roundabouts \\
\hline 50 & Dynamic assignments in cars \\
\hline 51 & Connection between assignments and roads \\
\hline 52 & Search of parking places \\
\hline 53 & Variable signs \\
\hline 54 & Data co-ordination in the public sector \\
\hline 55 & ISA in cars (Intelligent Speed Adaptation) \\
\hline 56 & Control systems as punishment \\
\hline 57 & Alternative fuel types \\
\hline 58 & Black box in cars \\
\hline 59 & Improved rescue equipment in cars \\
\hline 60 & Restrictions for mopeds \\
\hline 61 & Voluntarily use of bicycle helmet \\
\hline 62 & Integration of the Øresund Region \\
\hline 63 & Suppression of the toll at the Øresund Bridge \\
\hline 64 & Fixed link between Elsinore and Helsingborg (H-H) \\
\hline 65 & Fix linked across Femer Belt \\
\hline 66 & Competitive environmental profile of the Copenhagen Region \\
\hline 67 & Traffic closure of the Middle Age town of Copenhagen \\
\hline 68 & Improved public transport network \\
\hline
\end{tabular}

Table 5: The 2015 visions related to each of the two strategies.
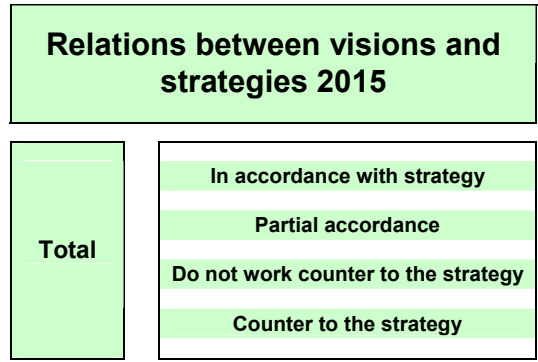

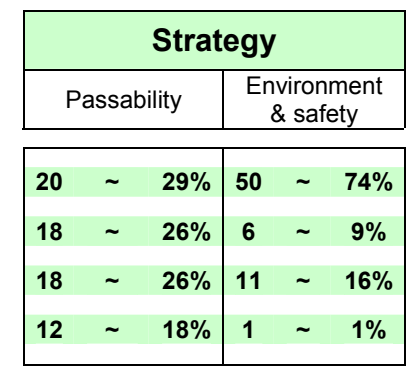

\section{Conclusions}

In Danish traffic planning the "Trafik 2005" report from the Danish Ministry of Transport published in 1993 is seen as a trend-breaking report in the way it applies a set of formulated 2005 visions. In this paper a new set of 2015 visions, formulated in 2005 based on brainstorm sessions, have been examined and compared to the 2005 visions. By use of a simple evaluating technique two strategies about passability and environment \& safety are compared based on their match degree with the visions. In this respect it is found that the new 2015 vision set obtains a more even distribution between the passability and environment \& safety strategies. Thus the more uneven relative shares of the 
2005 visions have changed. On the presumption that both vision sets represent examples of visionary planning towards sustainable transport this is interpreted as a shift in sustainability perception towards a broader planning framework.

Evidently, the simple quantitative counting technique is only indicative, as different visions necessarily cannot be associated with the same degree of importance. The visionary type of planning and the shown evaluation of the results may, however, demonstrate that strategy and sustainability can be monitored as part of transport planning development.

\section{References}

[1] Jeppesen, S. L. and Pedersen \& E. S., Regional trafik planlaegning frem mod 2015 - Visioner og metoder med udgangspunkt $i$ Øresunds regionen, Centre of Traffic and Transport, the Technical University of Denmark, p. 43, 2005.

[2] Jeppesen, S.L. and Leleur, S., Sustainable Development and Strategic Transport Management in the Øresund Region, Centre of Traffic and Transport, the Technical University of Denmark, 2006.

[3] United Nations, Development and international economic co-operation: Environment, Report of the World commission on Environment and development - note by the secretary-general, Forty-second session, item 83 (e) of the provisional agenda, United Nations, 1987, p. 54.

[4] Jeppesen, S. L. and Pedersen \& E. S., Regional trafik planlaegning frem mod 2015 - Visioner og metoder med udgangspunkt $i$ Øresunds regionen, Centre of Traffic and Transport, the Technical University of Denmark, p. 4, 2005.

[5] Trafikministeriet, Trafik 2005 - Problemstillinger, mål og strategier, Trafik ministeriet, 1993.

[6] Jeppesen, S. L. and Pedersen \& E. S., Regional trafik planlaegning frem mod 2015 - Visioner og metoder med udgangspunkt $i$ Øresunds regionen, Centre of Traffic and Transport, the Technical University of Denmark, 2005.

[7] Rosenhead, J. and Mingers, J., Rational Analysis for a Problematic World Revisited, Problem Structuring Methods for Complexity and Conflict, John Wiley \& Sons Ltd, pp. 26-38, 2002. 